\title{
SUB-ALTITUDE THERMO-HYGHROMETRIC COMPARISON IN URBAN AND RURAL AREA IN HIGH-ALTITUDE TROPICAL CLIMATE BY RPA/DRONE
}

\author{
BRÚSSOLO, Rafael Gotardi - rgbrussolo@gmail.com \\ Universidade de São Paulo - USP
}

\author{
VECCHIA, Francisco Arthur da Silva - fvecchia@sc.usp.br \\ Universidade de São Paulo - USP
}

\begin{abstract}
It is known that different types of land use and occupation (urban, industrial, rural, forest) alter the energy balance between the surface and the atmosphere. The comparison between surface and sub-altitude climatology data in urban and rural areas have still been a few studied. In this way, the proposed study aims to analyze and compare the values of air temperature and relative humidity near the surface (1.5m high) and at different heights (50m and $190 \mathrm{~m}$ of the surface) in urban and rural areas in São Carlos (SP), during nighttime in winter episodes, by means of thermohygrometer coupled in a quadricopter (four propellers) Remotely-Piloted Aircraft (RPA/Drone). The flight in the urban area was carried out on $07 / 13 / 2018$ and in the rural area on $07 / 26 / 2018$ between 7:30 p.m and 8:30 p.m. The results showed that in the urban area at night time the air temperature and relative humidity are higher near the surface concerning the sub-altitude data. In the rural area at night time, the air temperature is lower and the air relative humidity is higher to the surface compared to the sub-altitude data.
\end{abstract}

Keywords: Boundary layers. Urban x Rural. Thermal field. Methodological proposal. RPA/Drone.

\section{COMPARAÇÃO TERMOHIGROMÉTRICA DE SUB-ALTITUDE EM ÁREAS URBANAS E RURAIS EM CLIMA TROPICAL DE ALTITUDE POR MEIO DE VANT/DRONE}

RESUMO: Sabe-se que os diferentes tipos de uso e ocupação do solo (urbano, industrial, rural, florestal) alteram o balanço de energia entre a superfície e a atmosfera. A comparação entre os dados climatológicos de superfície e sub-altitude em áreas urbanas e rurais ainda é pouco estudada. Desta forma, o estudo proposto tem como objetivo analisar e comparar os valores de temperatura e umidade relativa do ar próximo à superfície ( $1,5 \mathrm{~m}$ de altura) e a diferentes alturas ( $50 \mathrm{~m}$ e $190 \mathrm{~m}$ da superfície) em áreas urbanas e rurais em São Carlos (SP), durante a noite em episódios de inverno, por meio de termo-higrômetros acoplados em um quadricóptero (VANT/Drone). O voo na área urbana foi realizado em 13/07/2018 e na área rural em 26/07/2018, das 19 h30 às 20h30. Os resultados mostraram que na área urbana no período noturno a temperatura e a umidade relativa do ar são maiores na superfície em relação aos dados de sub-altitude. $\mathrm{Na}$ área rural durante a noite, a temperatura do ar é mais baixa e a umidade relativa do ar é mais alta em comparação com os dados de sub-altitude.

Palavras-Chave: Camada limite, UrbanoxRural, Campo térmico, Proposta metodológica, Vant/DRONE.

COMPARACIÓN TERMO-HIGROMÉTRICA DE SUB-ALTITUD EN ÁREAS URBANAS Y RURALES EN CLIMA TROPICAL DE ALTITUD POR MEDIO DE VANT/DRONE

RESUMEN: Se sabe que los diferentes tipos de uso y ocupación del suelo (urbano, industrial, rural, forestal) alteran el balance de energía entre la superficie y la atmósfera. La comparación entre los datos climatológicos de superficie y sub-altitud en áreas urbanas y rurales todavía es poco estudiada. De esta forma, el estudio propuesto tiene como objetivo analizar y comparar los valores de temperatura y humedad relativa del aire cerca de la superficie $(1,5 \mathrm{~m}$ de altura) ya diferentes alturas $(50 \mathrm{~m}$ y $190 \mathrm{~m}$ de la superficie) en áreas urbanas y rurales en São Carlos (SP), durante la noche en episodios de invierno, por medio de termo-higrómetros acoplados en un cuadricóptero 
(VANT/Drone). El vuelo en el área urbana fue realizado el 13/07/2018 y en el área rural el $26 / 07 / 2018$, de las 19.30 a las $20 \mathrm{~h} 30$. Los resultados mostraron que en el área urbana en el período nocturno la temperatura y la humedad relativa del aire son mayores en la superficie en relación a los datos de sub-altitud. En el área rural durante la noche, la temperatura del aire es más baja y la humedad relativa del aire es más alta en comparación con los datos de sub-altitud.

Palabras Clave: Capa límite, UrbanoxRural, Campo térmico, Propuesta metodológica, Vant/DRONE.

\section{INTRODUCTION}

Even with the increase in the demand for meteorological studies by radiosonde, a great part is directed to observations of high layers of the atmosphere, which can present problems in the acquisition and transmission of information to the receiving station in the surface, as well as difficulties in establishing a plateau of continuous height with little oscillation due to airflow turbulence and the generation of high logistical costs with the terrestrial displacement to locate and collect the set of instruments coupled to the radiosonde.

When it comes to urban climate studies, knowing the influence of the city on climate elements is critical so that measures can be taken to mitigate the adverse effects of these local climate changes, highlighting thermal discomfort, air quality, and hydrometeorological effects.

Regarding the methodologies for the study of urban climate, we can emphasize the fixed points, the mobile transect, the surface temperature and currently the microclimatic modeling (AMORIM, 2019). All of these methodologies work with near-surface weather information.

Therefore, the proposed study aims to analyze the influence that urban areas can apply on climate elements in the sub-altitude atmosphere (above the urban canopy layer). Rural data are for comparison of data.

Furthermore, the proposal to use the RPA/Drone is to make the radiosonde process more efficient, faster and cheaper. In this study the air temperature and relative humidity were used, however, the RPA/Drone can carry several types of sensors, not exceeding its load limit. Moreover, it is important to know the functioning of the atmosphere just above the surface. This knowledge can contribute to a better understanding of the interaction between the different roughnesses (surfaces) and the atmosphere, providing subsidies for climatology, meteorology, agronomy and related areas.

Oke (1978) compared the daytime and nighttime temperature profiles in urban and rural areas. The author affirms out that during the day the air is heated on the earth's surface and rises to the cooler air of the boundary layer, where it is mixed with atmospheric air to form a constant temperature limit layer. The mixture takes warm air upwards, beyond the boundary layer, where the thermal inversion of hot air over cold air takes place. In rural areas, at night, the earth's surface is colder than the air above it. Once the air is no longer heated by the surface, there is no hot air. Instead, the air accommodates in a thermal inversion at ground temperature, or in a stable mass of cold air near the ground with warmer air above it. In this perspective, one can cite the works of Duckworth and Sandberg (1954), Davidson (1967), Bornstein (1968), Georgii et al. (1968), Clarke (1969), Mahrt (1999), Mestayer et al., (2005) and Pal et al., (2012). 
Thus, the work proposed here aims to analyze and compare the values of air temperature and relative humidity in urban and rural areas, at different vertical levels of the atmosphere $(50 \mathrm{~m}$ and $190 \mathrm{~m})$ in São Carlos, Brazil.

\section{MATERIALS AND METHODS}

The research proposed here is part of the ideas developed in a preliminary study published by Neves et al. (2015), whose objective was to evaluate the parameters of air temperature and relative humidity of the substrate of the Atmospheric Boundary Layer ( $A B L)$, in the vicinity of a lacustrine region in different synoptic situations, using a RPA/Drone and captive balloons to transport the thermo-hygrometric sensors, comparing these results with the data of the surface meteorological station.

The results showed that the air relative humidity presented superiority in the values when compared to the surface meteorological station. The RPA/Drone established practically inert height and position, making the measurements more uniform than the captive balloon. In this way, the authors stated that it is possible to use RPA/Drone as an alternative methodology in radiosonde studies.

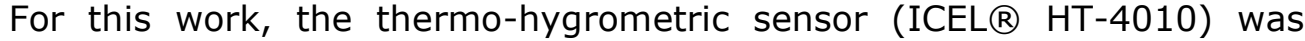
used. Although the flights were carried out during the night, it was decided to protect them with insulating material of the type durafoil $®$ silver and PVC pipes, due to possible turbulence. The device has USB interface for downloading data directly to the computer (Figure 1 ).
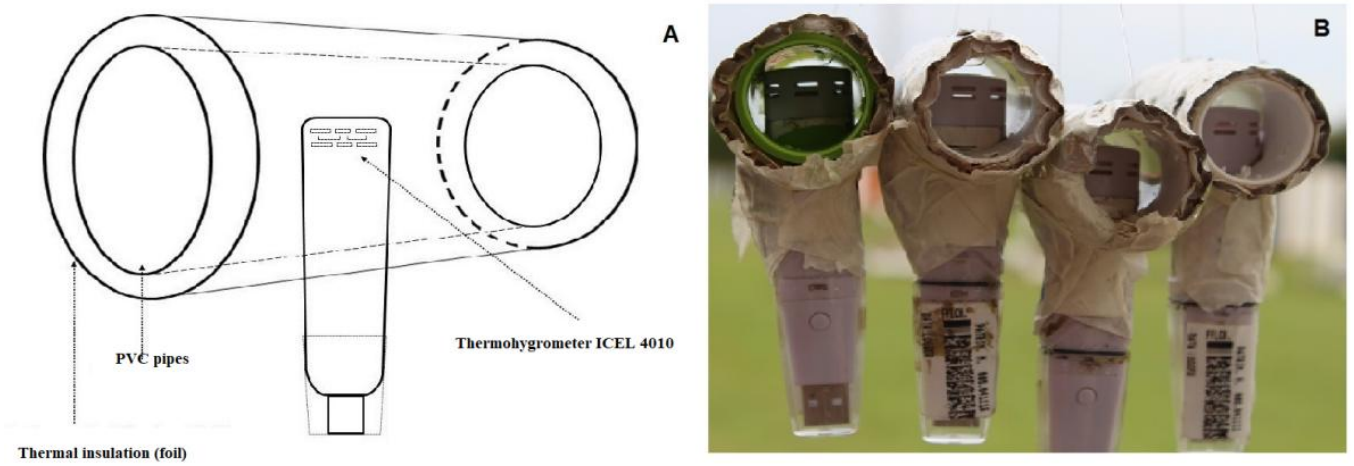

Figure 1 - Scheme of the meteorological shelter and thermo-hygrometric sensors (A); Sensor arrangement (B). Source: Adapted from Neves et al (2015).

The RPA/Drone used was quadricopter style (four propellers). It has an autopilot that controls it employing the fusion of the data of the sensors of Inertial Measurement Unit (IMU) and Global Positioning System (GPS) (Figure 2). 

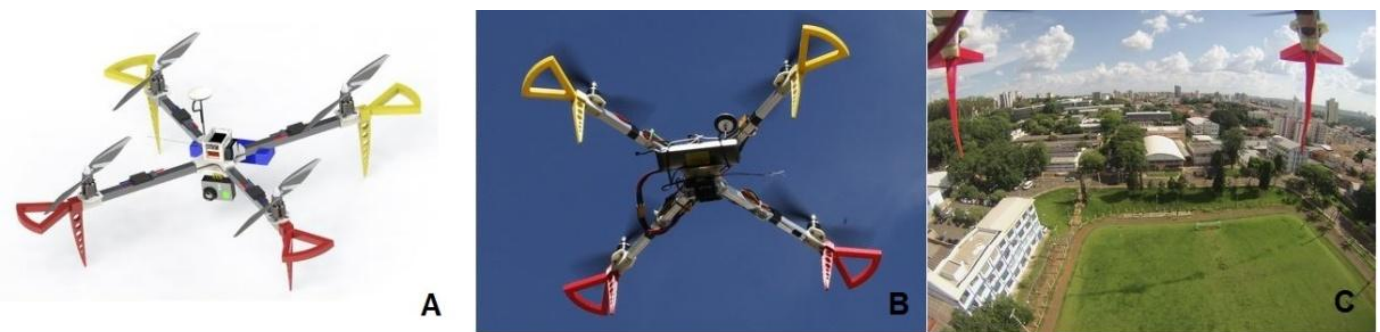

Figure 2 - Example of RPA/Drone (A), RPA/Drone in flight (B) and aerial image of Campus 1 São Carlos School of Engineering (C). Source: Adapted from Neves et al (2015).

The thermo-hygrometric sensors were suspended by nylon cables at $10 \mathrm{~m}$ away from the RPA/Drone to avoid turbulence. For data collection, the RPA/Drone remained in stable flight for a compatible time for "stabilization" of the sensors (previous tests showed that the sensor stabilized before 1 minute). The sensors were programmed to collect data every 10 seconds (Figure 3 ). The geometric height for the flight was obeyed.

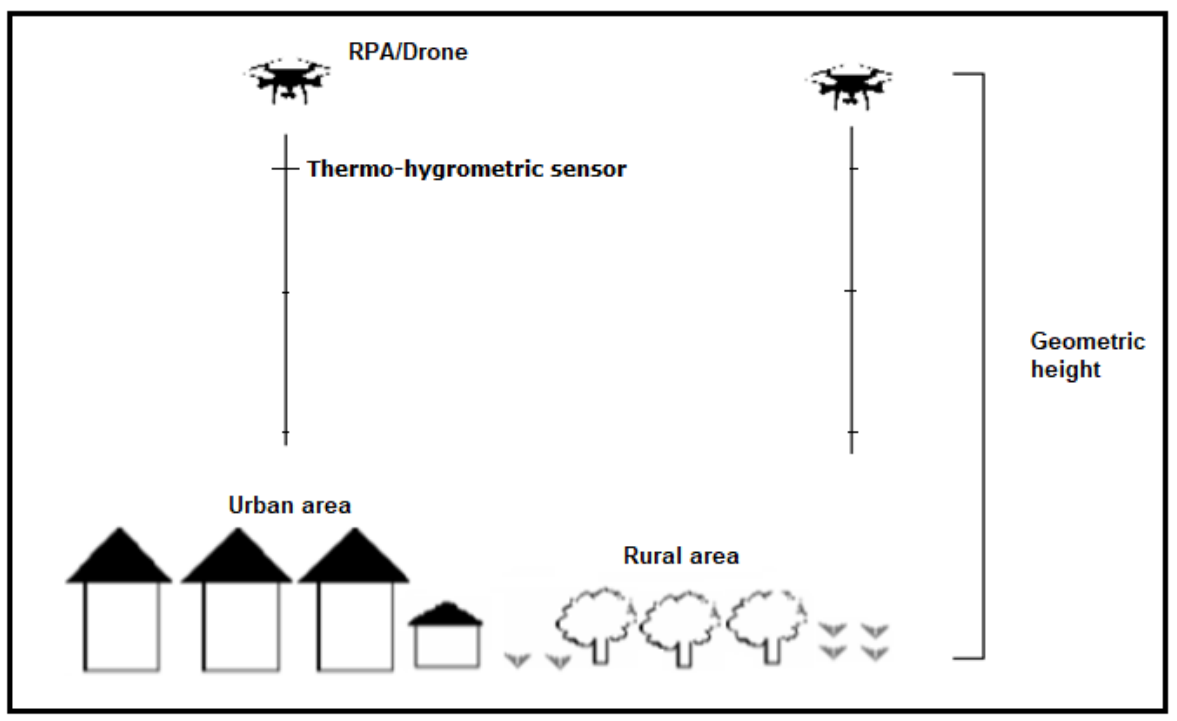

Figure 3 - Methodology adopted for urban and rural flight. Source: The author.

The advantage of using the RPA/Drone is its ability to remain stable amid turbulent winds. In contrast, the duration of the flight is restricted to an mean of 15 minutes due to battery wear.

The flights were held between 7:30 p.m and 8:30 p.m. First the flight was done in the urban area (07/13/2018) at 50m (the RPA/Drone remained stable at $10 \mathrm{~m}$ above the height of the sensor due to the nylon cable). From the moment that the RPA/Drone reached the height of $60 \mathrm{~m}$ was recorded 8 minutes of collection, recording the data every 10 seconds. At the end of this first collection, the RPA/Drone returned to the surface to change the battery and discharge the data.

In the second collection, the RPA/Drone reached a height of $200 \mathrm{~m}$ to the surface, remaining stable for 8 minutes and recording the air temperature and 
relative humidity information every 10 seconds, in the same manner as in the first flight $(50 \mathrm{~m})$. The same procedures were adopted for the flight in a rural area on $07 / 26 / 2018$.

During the flights, a sensor was also programmed to record the air temperature and relative humidity information on the surface (1.5m high) to compare them with the $50 \mathrm{~m}$ and $190 \mathrm{~m}$ highs data. Data collection at different heights occurred because $50 \mathrm{~m}$ is mean of the São Carlos urban canopy layer (buildings with 10 to 15 floors). Based on that, it was decided to collect data at $(50 \mathrm{~m})$ and another distant from the urban canopy layer $(190 \mathrm{~m})$, to verify to what vertical limit of the atmosphere the city can generate an urban climate.

It is worth pointing out that for the realization of the flight with the RPA/Drone were chosen areas with similar altitudes and flat surface (The characterizations are described in the source of the figures 8 and 10). Also, dates with atmospheric stability (clear sky and calm winds) and with similar air temperature and relative humidity, direction and wind speed characteristics.

For this characterization were used the images of the GOES 16 satellite of the Weather Prevision Center and Climate Studies (CPTEC/INPE), the radar images of the Institute of Meteorological Research (IPMET), surface weather data (net radiation, air temperature and relative humidity, direction and wind speed and rainfall) of the weather station of the Brazilian Agricultural Research Corporation (EMBRAPA) (rural area) and IAU/USP-São Carlos weather station data located in the urban area (air temperature and relative humidity and direction and wind speed).

For the data statistical analysis, the Scatter Diagram, the Coefficient of Determination $\left(R^{2}\right)$, the Mean, the Standard Deviation and the Pearson's Correlation Coefficient $(r)$ were used.

\subsection{BRIEF CHARACTERIZATION OF THE STUDY AREA}

São Carlos is located in the central region of the State of São Paulo Brazil (470 43 '04 "- 480 05' 26" W, 21035 '45 "- 220 09' 30" S) (Figure 4). It has a total area of approximately $1.140 \mathrm{~km} 2$, with the urban area accounting for $6 \%$ of the total area $(67.5 \mathrm{~km} 2)$, the urban area occupied is $33 \mathrm{~km} 2$, population density 195.15 Inhabitants $/ \mathrm{km} 2$. According to the Brazilian Institute of Geography and Statistics (IBGE) estimates (2018), São Carlos has 249.415 thousand inhabitants.

The mean altitude of the municipality is $850 \mathrm{~m}$ above sea level. The lower relief areas $(520 \mathrm{~m})$ are in the northern portion and the highest $(1000 \mathrm{~m})$ in the Southeast portion. 


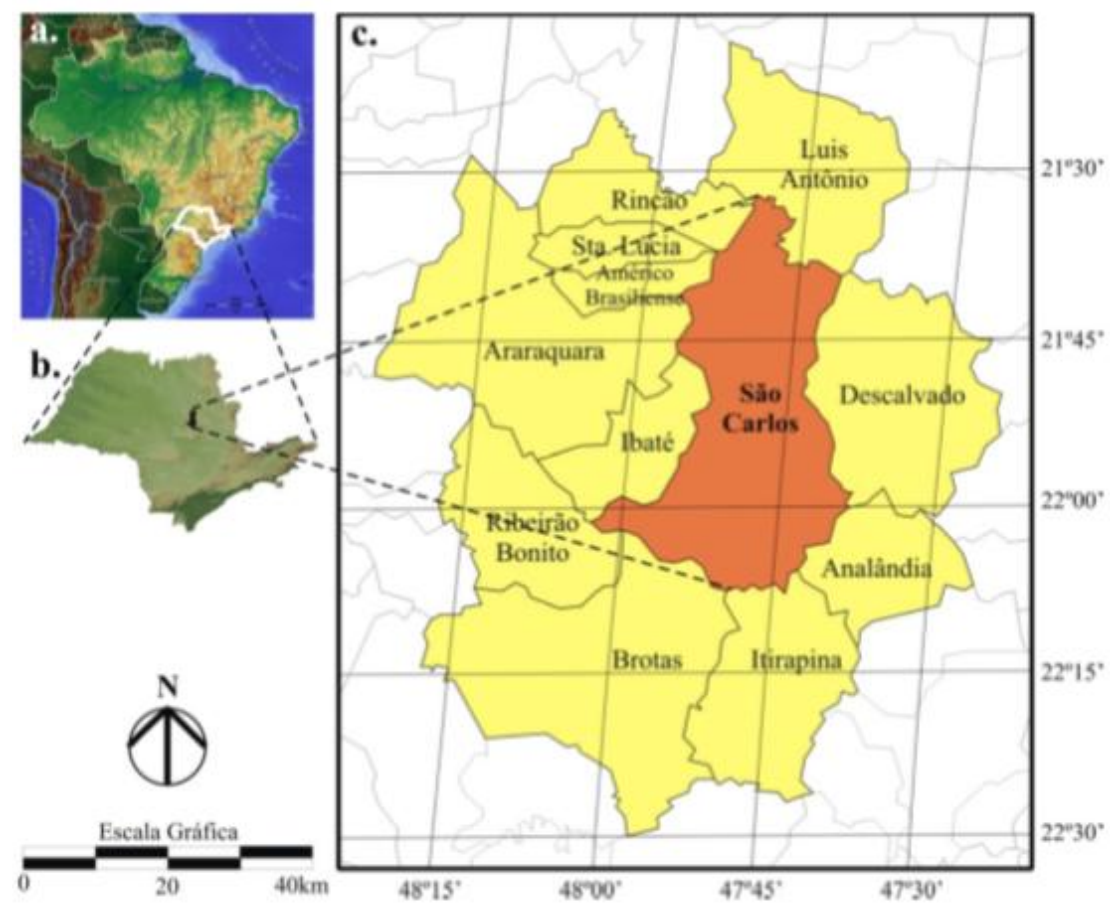

Figure 4 - (a) Location of the State of São Paulo in Brazil, (b) location of the municipality of São Carlos in the State of São Paulo, (c) neighboring municipalities and geographic location of the municipality of São Carlos. Source: Barbosa, 2009.

\section{RESULTS AND DISCUSSION}

Figure 5 provides the net radiation, air temperature and relative humidity, direction and wind speed of 07/13/2018 (blue line) and 07/26/2018 (red line). For this characterization data were used every 15 minutes from the Embrapa weather station.

With the analysis of the episode it was found that on July 13,2018 , the mean air temperature was $18.4^{\circ} \mathrm{C}$, the air relative humidity varied between $50 \%$ and $11 \%$, the mean wind speed was $1.3 \mathrm{~m} / \mathrm{s}$ and predominant direction was from the South quadrant. The sky passed with few clouds and there was no rain. Analyzing some previous days together with the information of $07 / 13 / 2018$, it was verified that the Atlantic Polar Mass was operating in the region of São Carlos, BR.

For July 26th, the mean air temperature was $19.5^{\circ} \mathrm{C}$, the air relative humidity varied between $71 \%$ and $30 \%$, the mean wind speed was $1.7 \mathrm{~m} / \mathrm{s}$ and the predominant direction of the East quadrant. The sky remained with few clouds and there was no rain. Thereby, the performance of the Atlantic Tropical Mass was verified. 


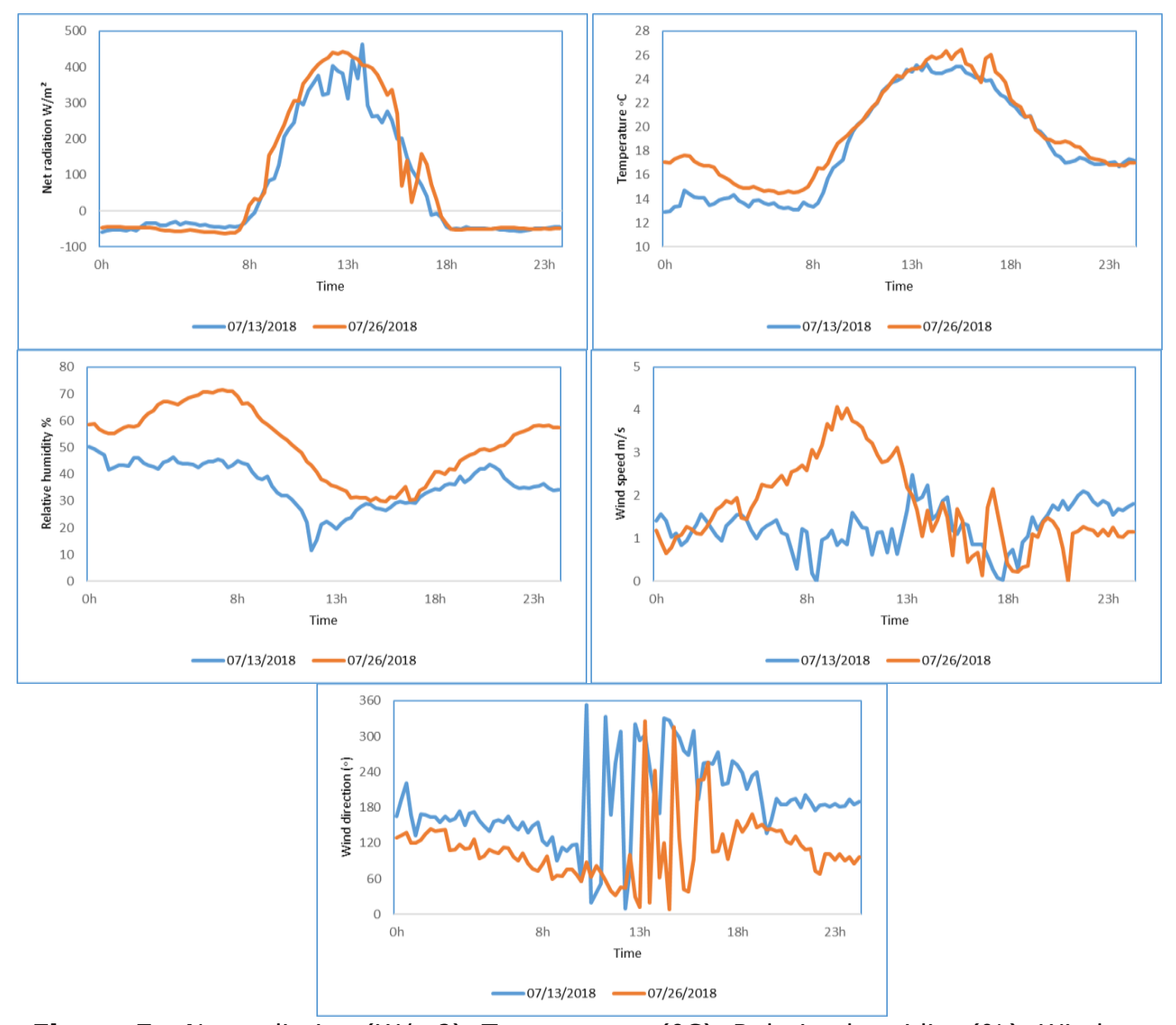

Figure 5 - Net radiation $\left(\mathrm{W} / \mathrm{m}^{2}\right)$, Temperature $\left({ }^{\circ} \mathrm{C}\right)$, Relative humidity $(\%)$, Wind speed $(\mathrm{m} / \mathrm{s})$ and Wind direction $\left({ }^{\circ}\right)$ on $07 / 13 / 2018$ e $07 / 26 / 2018$. Source: Embrapa Weather Station.

Figures 6 and 7 illustrate the images of the IPMET meteorological radar and the GOES 16 satellite of $07 / 13 / 2018$ and $07 / 26 / 2018$. The use of these images helps in understanding the synoptic conditions on the day of the flight. 

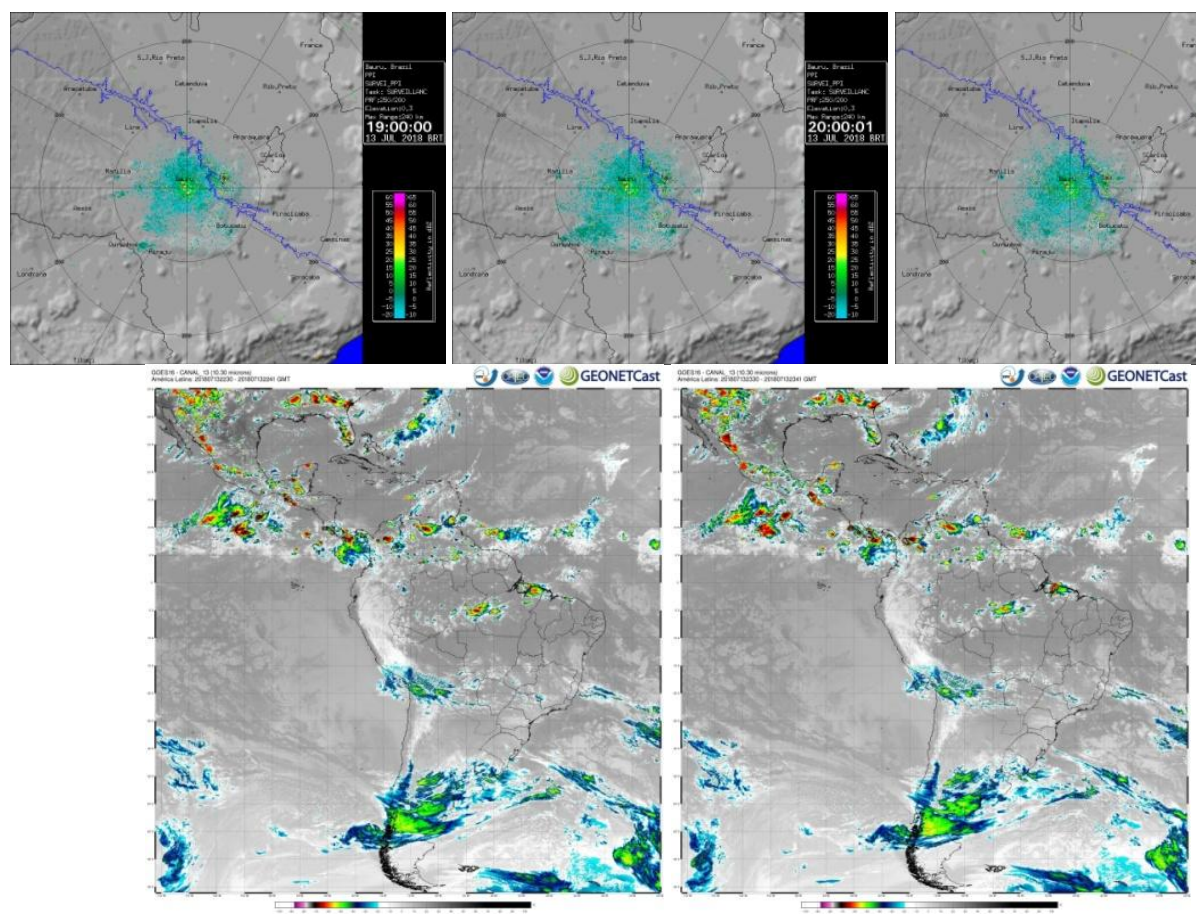

Figure 6 - Images of the meteorological radar of the IPMET and the GOES 16 satellite of the $07 / 13 / 2018$ near the time of the flight. Source: IPMET and CPTEC/INPE.
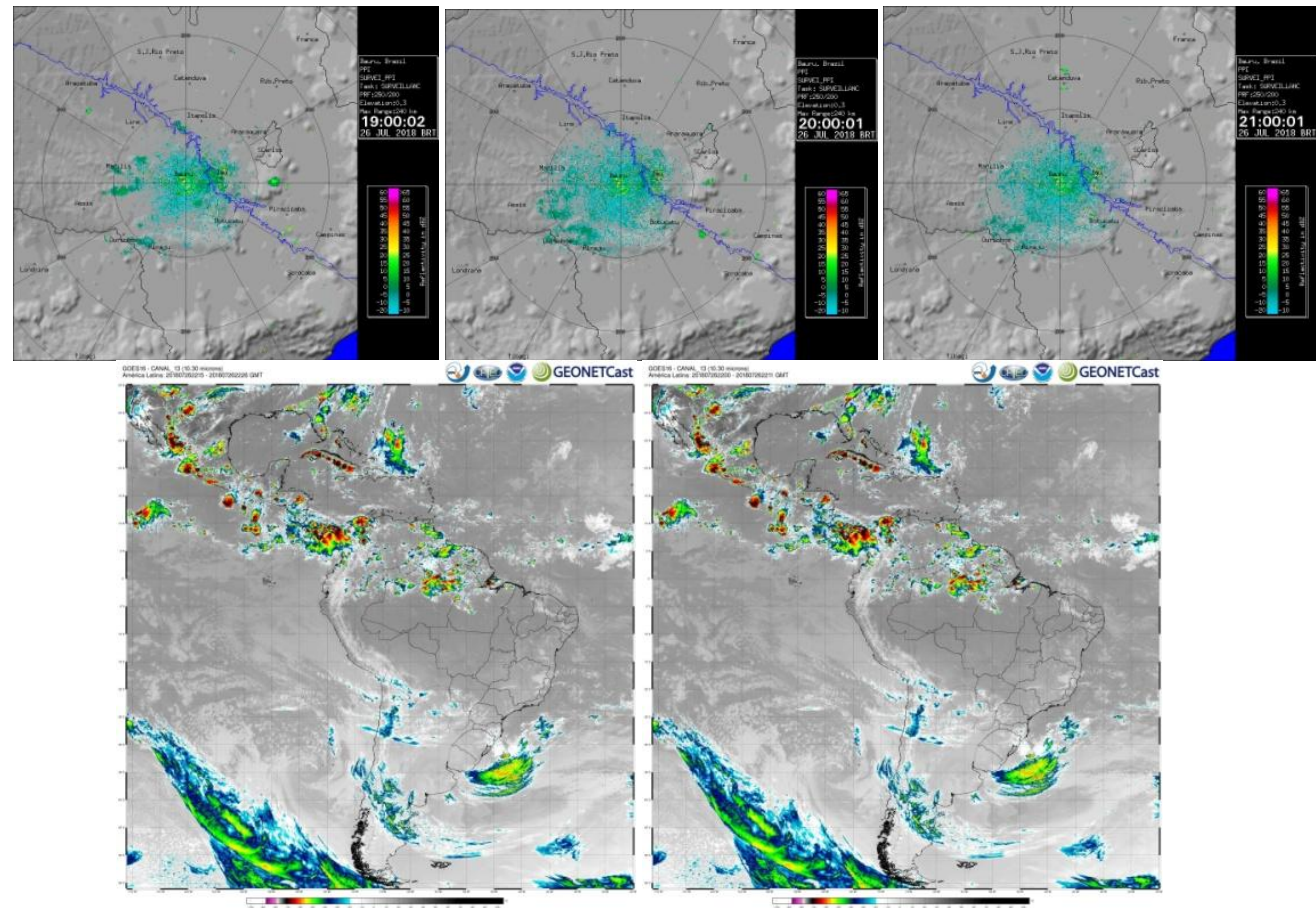

Figure 7 - Images of the meteorological radar of the IPMET and the GOES 16 satellite of the $07 / 26 / 2018$ near the time of the flight. Source: IPMET and CPTEC/INPE. 


\subsection{URBAN AREA RESULTS}

During the flight, the wind speed varied from 1.2 to $1.6 \mathrm{~m} / \mathrm{s}$ with South's predominant direction, no clouds and there was no rain, according to the information of IAU/USP-São Carlos weather station, located $1 \mathrm{~km}$ from the flight location in the urban area.

The collection with the RPA/Drone starts from the moment the desired flight height is reached. In this way, it was verified that at the beginning of the collection the air temperature was greater in sub-altitude than near the surface. The turbulence of the rise and the "stabilization" of the sensor may have favored this behavior. From the moment of the stability of the flight, it was perceived that the sub-altitude temperature begins to fall and stabilize below the values close to the surface.

According to Oke (1978) during the day the air is heated on the earth's surface and rises to the cooler air of the boundary layer, where it is mixed with atmospheric air to form a constant temperature limit layer. The mixture carries hot air upwards, beyond the boundary layer, where a thermal inversion of the hot air over the cold air takes place. The boundary layer is thicker and hotter in urban areas than in rural areas because urban surfaces can absorb and retain heat for longer. Therefore, this heat produced by the cities can supply the thermal inversions that hold the hot air near the ground in nocturnal periods, as it was diagnosed in this research.

Regarding the air relative humidity, its negative correlation with the air temperature close to the surface $(1.5 \mathrm{~m})$ and of the sub-altitude (50 and $190 \mathrm{~m}$ ) was observed, that is, when the air temperature values increase the values of air relative humidity decrease and vice versa. It should be noted that the values of air relative humidity near the surface were higher with the sub-altitude data. Generally, occurs the decrease of the air relative humidity with altitude.

Figure 8 provides the RPA/Drone flight location in the urban area and Figure 9 the data of air temperature and relative humidity in the urban area between 7:30 p.m and 8:30 p.m. on 07/13/2018 at 50m and $1.5 \mathrm{~m}$ and at $190 \mathrm{~m}$ and $1.5 \mathrm{~m}$ of surface height. The results showed that the urban area of São Carlos at night has the highest air temperature $(1.5 \mathrm{~m})$ in comparison with the sub-altitude data (50 and $190 \mathrm{~m}$ ). 


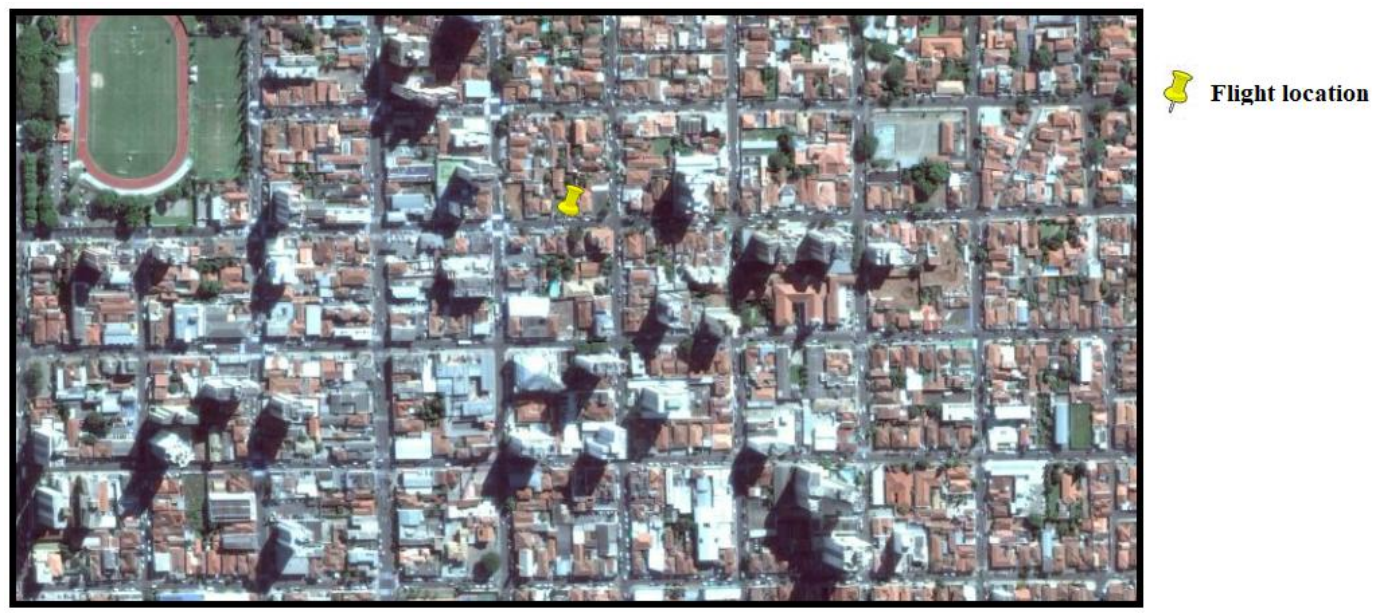

Figure 8 - Flight location in urban area on 07/13/2018. Altitude: $874 \mathrm{~m}$. Relief: Flat surface. Source: Earth Pro, 2018.
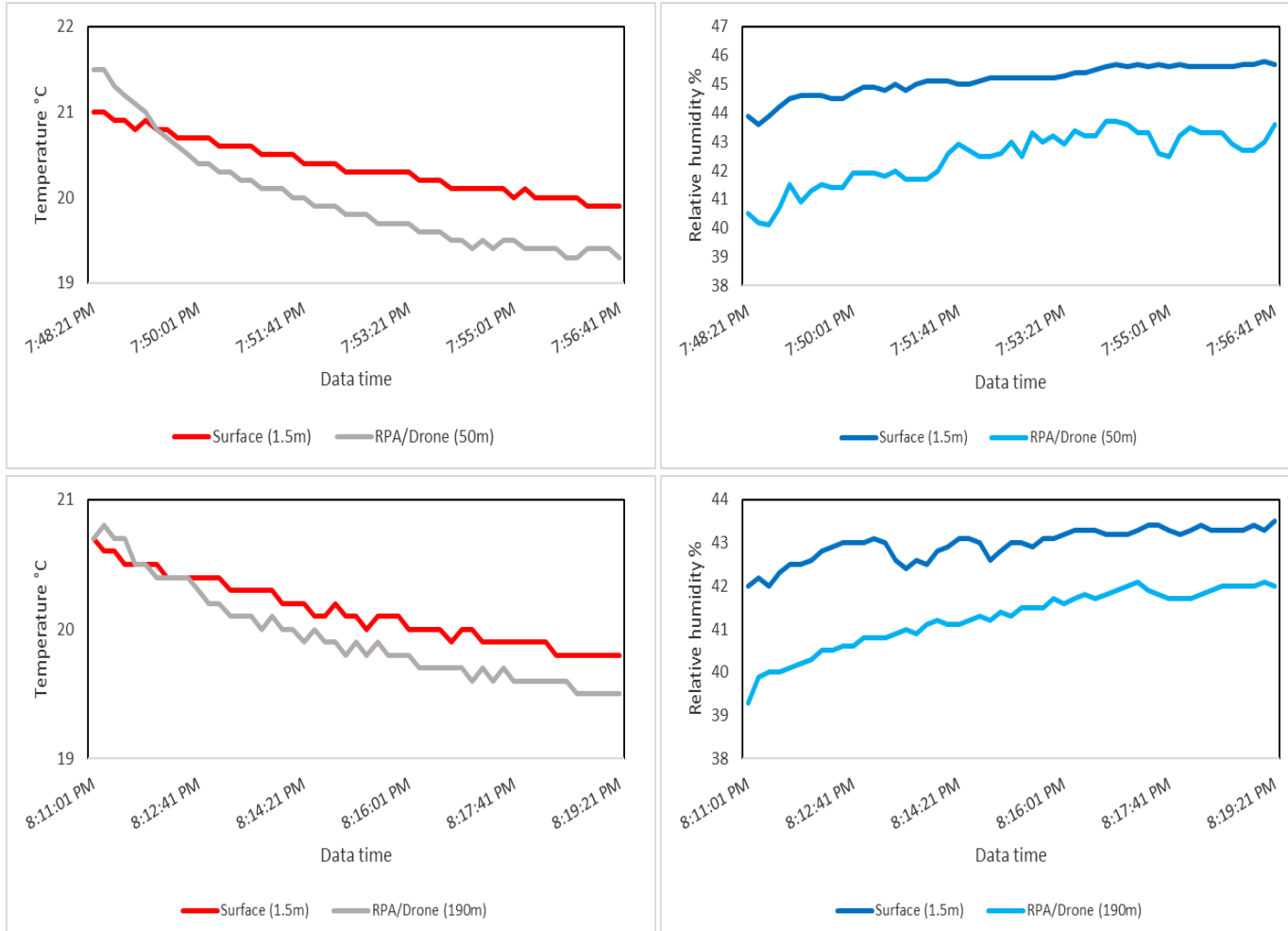

Figure 9 - Air temperature and relative humidity at $1.5 \mathrm{~m}$ and $50 \mathrm{~m}$ and at $1.5 \mathrm{~m}$ and $190 \mathrm{~m}$ of surface height between 7:30 p.m and 8:30 p.m. on 07/13/2018 in urban area.Source: Research Data, 2018.

Analyzing the temperature data in figure 9, it was found that due to the absorption of solar radiation in the urban area, the air closer to the ground is usually warmer. As the hot air mass rises, it cools and continues the ascension process by finding denser air masses than it. This process causes the near- 
ground air mass to up. In this way, comparing the sub-altitude temperature with the surface temperature values, no differences higher than $2^{\circ} \mathrm{C}$ were found. This characterization can be explained by the city's hot airflow reaching the upper layers of the atmosphere (hot air convection).

This characterization agrees with the statements of Demarrais (1961), Bornstein (1968), Clarke (1969), Oke (1978), Godowitch et al (1985) and Pal (2012) when the authors state that warmer urban surfaces create a thicker boundary layer above which temperatures are reversed and equal to the rest of the troposphere. The temperature within the boundary layer is approximately constant due to the swirls that keep the air well mixed.

Figure 10 shows the Scatter Diagram and the Coefficient of Determination $\left(R^{2}\right)$ of air temperature and relative humidity collected in the urban area $(1.5 \mathrm{~m} / 50 \mathrm{~m}$ and $1.5 \mathrm{~m} / 190 \mathrm{~m})$. For this analysis, sub-altitude data was placed as a dependent variable and surface data as an independent variable.

Analyzing this information, it was discovered that in the case of temperature, $92.85 \%$ and $94.1 \%$ of the dependent variable (sub-altitude data) can be explained by the regressors present in the statistical model. Relative humidity has the following values: $83.26 \%$ and $75.81 \%$.
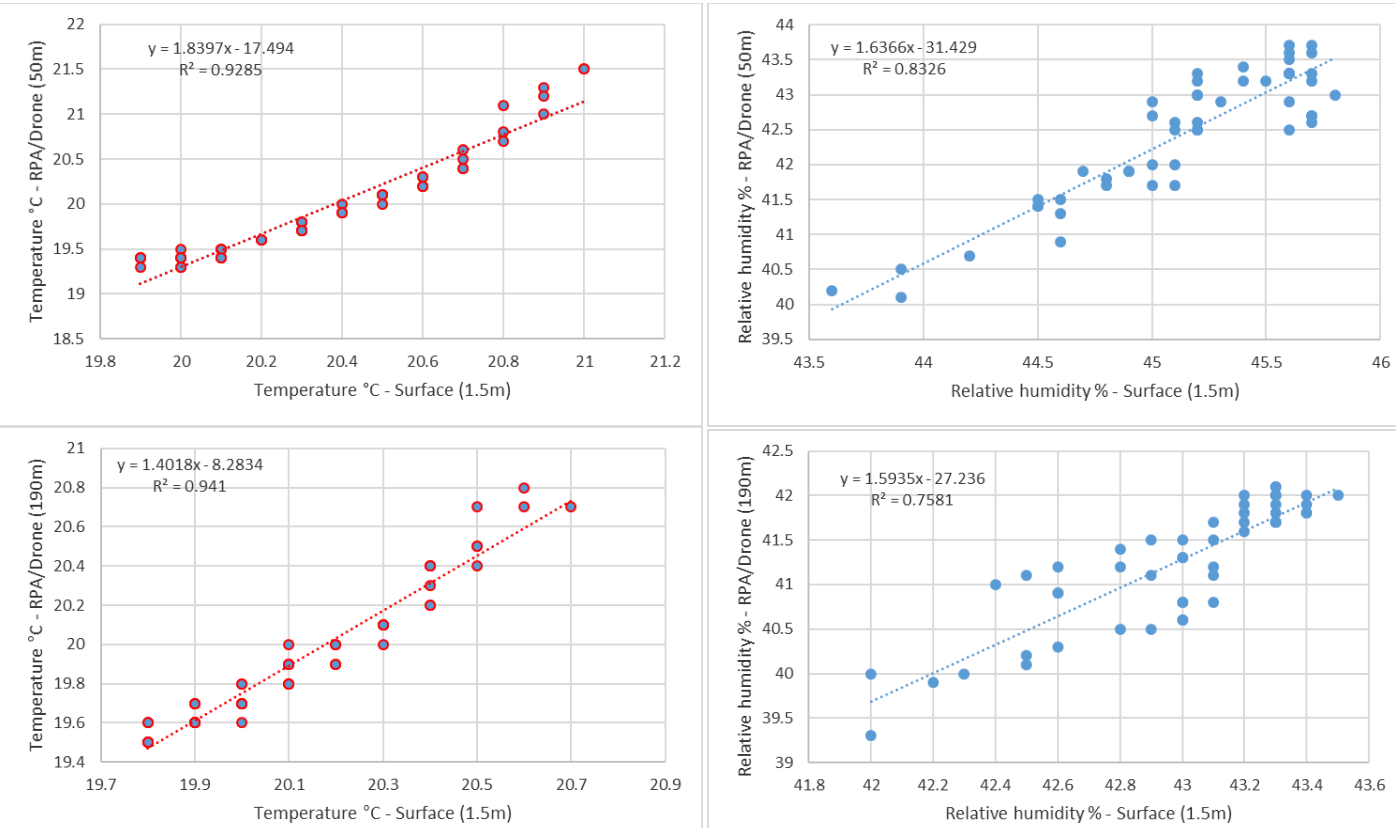

Figure 10 - Scatter Diagram and Coefficient of Determination $\left(R^{2}\right)$ at $1.5 \mathrm{~m}$ and $50 \mathrm{~m}$ and at $1.5 \mathrm{~m}$ and $190 \mathrm{~m}$ of surface height between 7:30 p.m and 8:30 p.m. on 07/13/2018 in urban area. Source: Research Data, 2018.

Tables 1 and 2 provide the Mean, Standard Deviation and Pearson's Correlation Coefficient ( $r$ ) for surface and sub-altitude data. As highlighted earlier, surface data $(1.5 \mathrm{~m})$ is higher than sub-altitude data $(50 \mathrm{~m}$ and $190 \mathrm{~m})$, both in air temperature and relative humidity. 
The low Standard Deviation observed is justified by the short data collection period ( 8 minutes), as temperature and humidity do not change rapidly.

Pearson's Correlation Coefficient ( $r$ ) shows that the variables are directly proportional (when the independent variable increases, the dependent increases as well), which affirms the dependency relationship of atmospheric behavior of sub-altitude with the surface.

Table 1 - Mean, Standard Deviation, and Pearson's Correlation Coefficient $(r)$ at $1.5 \mathrm{~m}$ and $50 \mathrm{~m}$ of surface height between 7:30 p.m and 8:30 p.m. on 07/13/2018 in urban area.

Source: Research Data, 2018.

\begin{tabular}{l|c|c|c|c}
\hline & \multicolumn{2}{|c|}{ Temperature } & \multicolumn{2}{c}{ Relative humidity } \\
\hline Height & $\mathbf{1 . 5 m}$ & $\mathbf{5 0 m}$ & $\mathbf{1 . 5 m}$ & $\mathbf{5 0 m}$ \\
\hline Mean & $20.3^{\circ} \mathrm{C}$ & $19.8^{\circ} \mathrm{C}$ & $45.2 \%$ & $42.6 \%$ \\
\hline Standard Deviation & 0.32 & 0.61 & 0.52 & 0.94 \\
\hline Correlation $(r)$ & \multicolumn{2}{|c|}{0.96} & \multicolumn{2}{c}{0,91} \\
\hline
\end{tabular}

Table 2 - Mean, Standard Deviation, and Pearson's Correlation Coefficient $(r)$ at $1.5 \mathrm{~m}$ and $190 \mathrm{~m}$ of surface height between 7:30 p.m and 8:30 p.m. on 07/13/2018 in urban area.

\begin{tabular}{l|c|c|c|c}
\hline & \multicolumn{2}{|c|}{ Temperature } & \multicolumn{2}{c}{ Relative humidity } \\
\hline Height & $\mathbf{1 . 5 m}$ & $\mathbf{1 9 0}$ & $\mathbf{1 . 5 m}$ & $\mathbf{1 9 0 m}$ \\
\hline Mean & $20.1^{\circ} \mathrm{C}$ & $19.9^{\circ} \mathrm{C}$ & $43.1 \%$ & $41.4 \%$ \\
\hline Standard Deviation & 0.25 & 0.36 & 0.37 & 0.69 \\
\hline Correlation $(r)$ & \multicolumn{2}{|c}{0.97} & \multicolumn{2}{c}{0.87} \\
\hline
\end{tabular}

Source: Research Data, 2018.

In the following item will be worked the flight information in the rural área on $07 / 26 / 2018$.

\subsection{RURAL AREA RESULTS}

During the flight, the wind speed varied from 0 to $1.5 \mathrm{~m} / \mathrm{s}$ with predominant Eastern direction, no clouds and there was no rain, according to the weather station of the Brazilian Agricultural Research Corporation (EMBRAPA), located $500 \mathrm{~m}$ from the flight location in the rural area.

The results showed that the rural area of São Carlos at night has the air temperature near the surface $(1.5 \mathrm{~m})$ lower than the sub-altitude data (50 and $190 \mathrm{~m}$ ) (Figure 12). The land cover type in rural areas (predominance of forage vegetation, shrubs, small, medium and large trees) does not have the same capacity to absorb and retain heat to urban surfaces (asphalt, concrete, etc.). Therefore, the rural surface loses heat more quickly and the air above it is no longer heated, making it possible to get cold air near the surface with a warmer air layer above it (OKE, 1978), as diagnosed in this research. 
The air relative humidity was inversely proportional to air temperature (higher values of air temperature, lower values of the relative humidity of air and vice versa).

The higher air relative humidity in a rural area compared in the urban area can be explained in two ways:

$>$ On this day was operating under São Carlos the Atlantic Tropical Mass that brought more moisture than the Atlantic Polar Mass that acted on $07 / 13 / 2018$.

$>$ When comparing the air relative humidity data between the Embrapa weather station (rural area) and the IAU/USP-São Carlos weather station (urban area) on $07 / 26 / 2018$, it was found that the mean air relative humidity in the period data collection (7:30 p.m and 8:30 p.m.) at Embrapa was 46\% and at IAU/USP-São Carlos was $34 \%$. This characterization demonstrates that the land cover types (surfaces with undergrowth, shrubs and medium and large trees), since the land use and the vegetal cover predominant in a region express the interactions between the available energy (net radiation) to the surfaceatmosphere system and its partition in sensible heat (air heating) and latent (evaporation) flows, which contributes to the air relative humidity increase.

Figure 11 demonstrates the RPA/Drone flight location in a rural area. Figure 12 provides the data of air temperature and relative humidity in the rural area between 7:30 p.m and $8: 30$ p.m. on $07 / 26 / 2018$ at $50 \mathrm{~m}$ and $1.5 \mathrm{~m}$ and $190 \mathrm{~m}$ and $1.5 \mathrm{~m}$ of surface height.

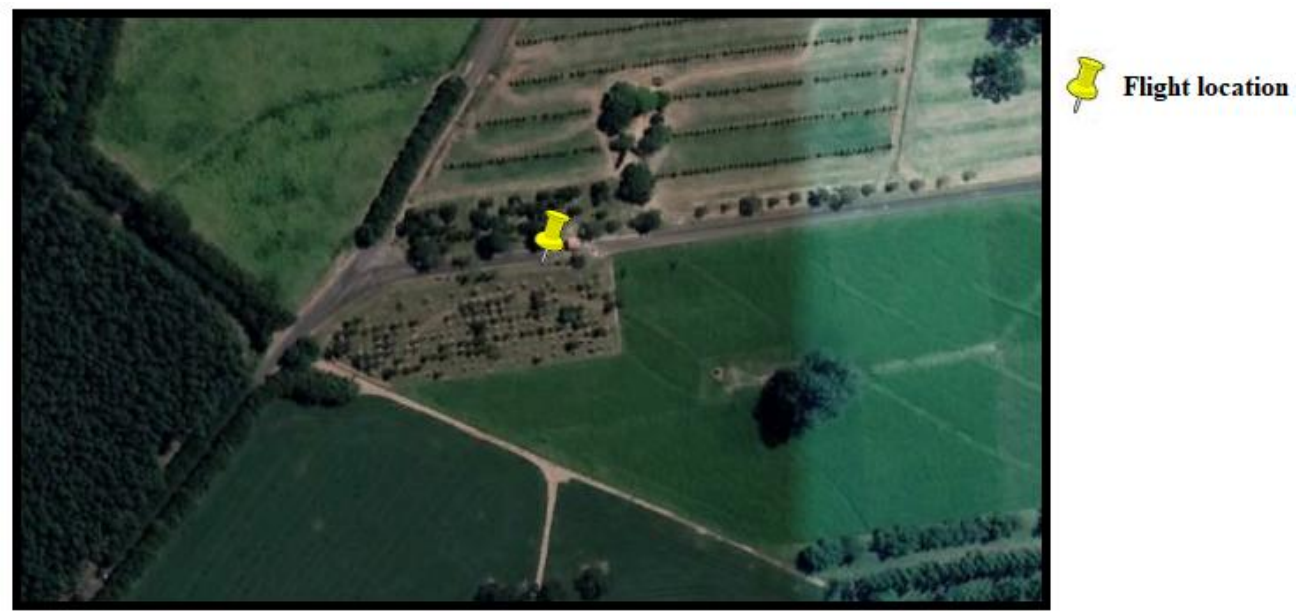

Figure 11 - Flight location in rural area on 07/26/2018. Altitude: $880 \mathrm{~m}$. Relief: Flat surface. Source: Earth Pro, 2018 

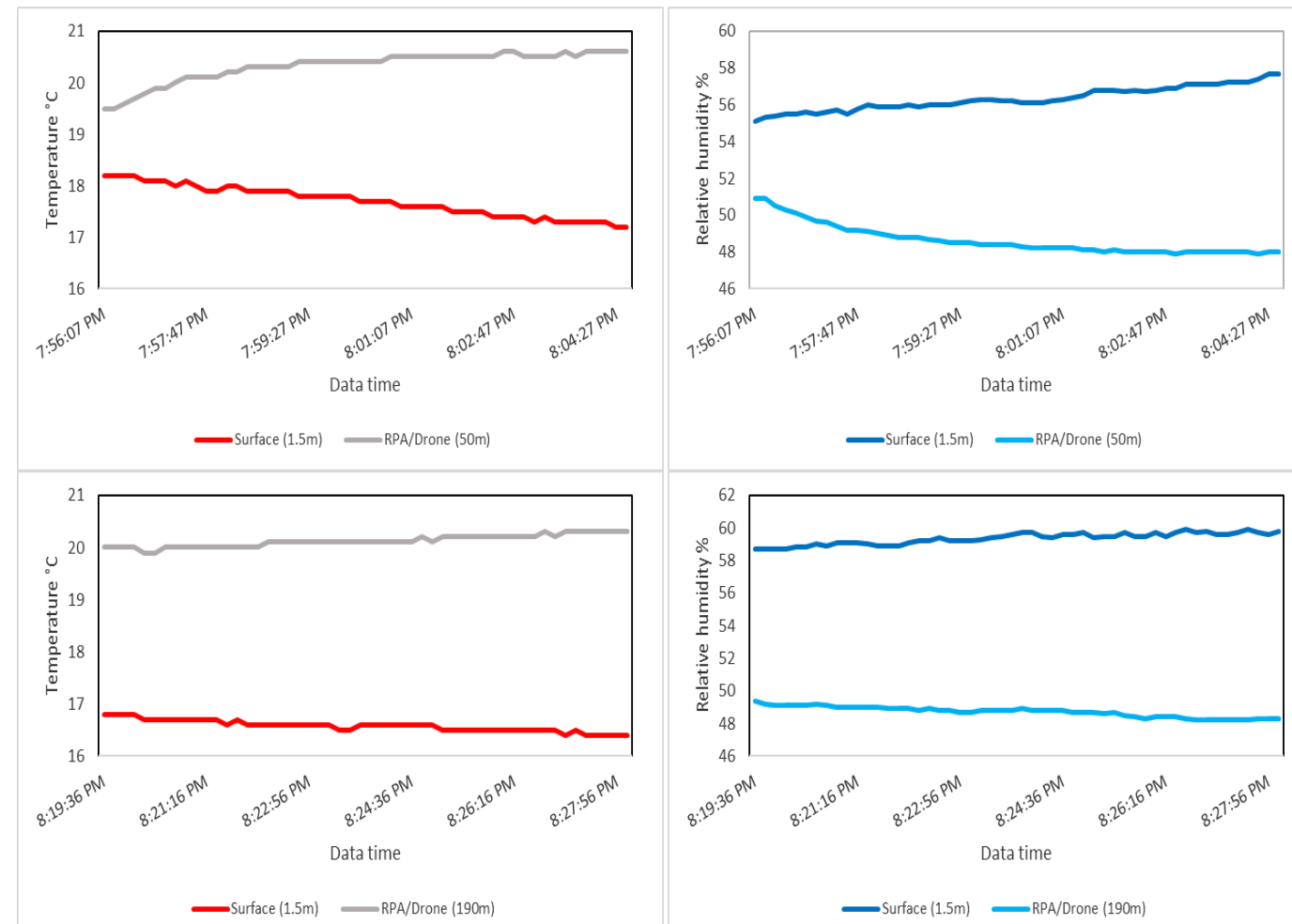

Figure. 12 - Air temperature and relative humidity at $1.5 \mathrm{~m}$ and $50 \mathrm{~m}$ and at $1.5 \mathrm{~m}$ and $190 \mathrm{~m}$ of surface height between 7:30 p.m and 8:30 p.m. on 07/26/2018 in rural area. Source: Research Data, 2018.

It was found that at night, air over rural areas cools, thus creating a thermal inversion of hot air over colder surface air. Temperature inversions are a result of other weather conditions in an area. They occur most often when a warm, less dense air mass moves over a dense, cold air mass. This can happen for example when the air near the ground rapidly loses its heat on a clear night. In this situation, the ground becomes cooled quickly while the air above it retains the heat the ground was holding during the day (ANDRÉ; MAHRT, 1982). This characterization corroborates Godowitch et al (1985) when the authors performed rural temperature transects in St. Louis, Missouri (USA) and Mahrt (1999) in his study about stratified atmospheric boundary layers.

Figure 13 shows the Scatter Diagram and the Coefficient of Determination $\left(\mathrm{R}^{2}\right)$ of air temperature and relative humidity collected in the rural area $(1.5 \mathrm{~m} / 50 \mathrm{~m}$ and $1.5 \mathrm{~m} / 190 \mathrm{~m})$. In the rural area, the temperature of the dependent variable (sub-altitude data) can be explained by $75.74 \%(50 \mathrm{~m})$ and $79.06 \%(190 \mathrm{~m})$ of the adopted statistical model. Relative humidity presented $70.21 \%$ and $70.04 \%$. 

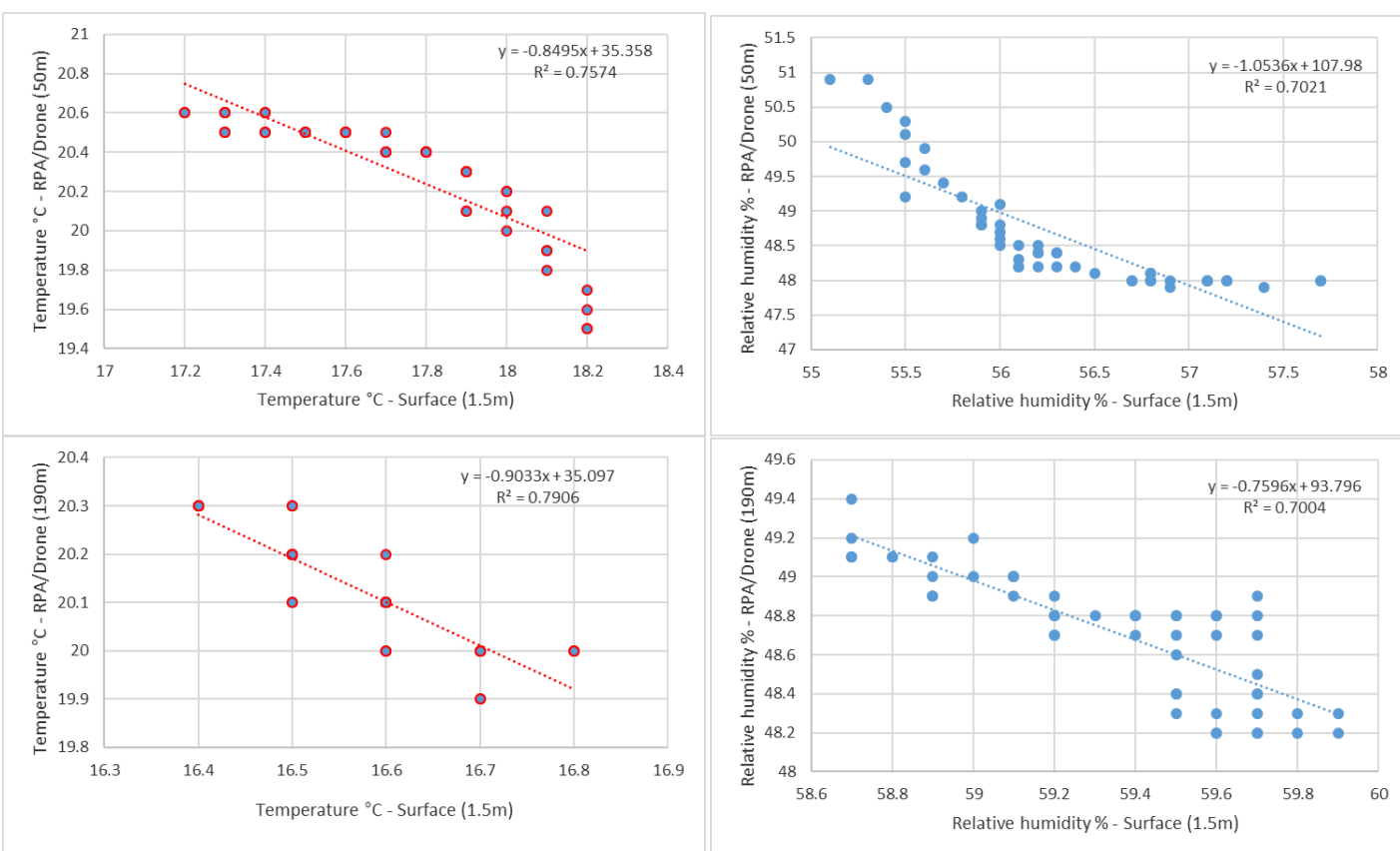

Figure 13 - Scatter Diagram and Coefficient of Determination $\left(R^{2}\right)$ at $1.5 \mathrm{~m}$ and $50 \mathrm{~m}$ and at $1.5 \mathrm{~m}$ and $190 \mathrm{~m}$ of surface height between 7:30 p.m and 8:30 p.m. on 07/26/2018 in rural area. Source: Research Data, 2018.

Tables 3 and 4 provide the Mean, Standard Deviation and Pearson's Correlation Coefficient ( $r$ ) for surface and sub-altitude data. The air near the surface was colder and wetter than that of sub-altitude.

The low value for the Standard Deviation occurred to the same explanation in the results of the urban area.

Pearson's Correlation Coefficient ( $r$ ) shows that the variables are inversely proportional (when the independent variable increases, the dependent decreases). These results corroborate the statements of Oke (1978) and André; Marht (1982) when the authors state that the rural surface cools faster and in contrast, sub-altitude air retains the heat that was on the surface.

Table 3 - Mean, Standard Deviation, and Pearson's Correlation Coefficient $(r)$ at $1.5 \mathrm{~m}$ and $50 \mathrm{~m}$ of surface height between 7:30 p.m and 8:30 p.m. on 07/26/2018 in rural area.

\begin{tabular}{l|c|c|c|c}
\hline & \multicolumn{2}{|c|}{ Temperature } & \multicolumn{2}{c}{ Relative humidity } \\
\hline Height & $\mathbf{1 . 5 m}$ & $\mathbf{5 0 m}$ & $\mathbf{1 . 5 m}$ & $\mathbf{5 0 m}$ \\
\hline Mean & $17.7^{\circ} \mathrm{C}$ & $20.4^{\circ} \mathrm{C}$ & $56.2 \%$ & $48.3 \%$ \\
\hline Standard Deviation & 0.30 & 0.29 & 0.64 & 0.80 \\
\hline Correlation $(r)$ & \multicolumn{2}{|c|}{-0.87} & \multicolumn{2}{c}{-0.83} \\
\hline
\end{tabular}

Source: Research Data, 2018. 
Table 4 - Mean, Standard Deviation, and Pearson's Correlation Coefficient $(r)$ at $1.5 \mathrm{~m}$ and $190 \mathrm{~m}$ of surface height between 7:30 p.m and 8:30 p.m. on 07/26/2018 in rural area.

\begin{tabular}{l|c|c|c|c}
\hline & \multicolumn{2}{|c|}{ Temperature } & \multicolumn{2}{c}{ Relative humidity } \\
\hline Height & $\mathbf{1 . 5 m}$ & $\mathbf{1 9 0 m}$ & $\mathbf{1 . 5 m}$ & $\mathbf{1 9 0 m}$ \\
\hline Mean & $16.6^{\circ} \mathrm{C}$ & $20.1^{\circ} \mathrm{C}$ & $59.4 \%$ & $48.8 \%$ \\
\hline Standard Deviation & 0.11 & 0.11 & 0.35 & 0.32 \\
\hline Correlation (r) & \multicolumn{2}{|c|}{-0.88} & \multicolumn{2}{c}{-0.83} \\
\hline
\end{tabular}

Source: Research Data, 2018.

\section{CONCLUSIONS}

This study attempts to understand how the different land cover types can interfere in the behavior of the climatic elements (in this case the air temperature and relative humidity) in different vertical levels of the atmosphere. This research contributes to the works of Demarrais (1961), Bornstein (1968), Oke (1978) and Pal (2012).

Therefore, it is important to work with this theme due to a better understanding of the urban microclimate. In this case study, it was observed how the sub-altitude atmosphere in urban and rural areas is influenced by the different types of land cover, especially regarding the changes in the energy balance between the city and the rural. Comparing atmospheric behavior between the two areas (urban and rural), it was noted how the surface can change the convective air flows.

It must be stressed that the study was conducted in an area of HighAltitude Tropical Climate. Studying this type of atmospheric behavior in locations with distinct climatic characteristics is important to better understand the surface/atmosphere relationship.

Understanding this influence and its meteorological repercussions is fundamental for urban and rural planning and design to improve the aspects of thermal discomfort, air quality, hydrometeorological effects, and others.

In the case of the use of RPA/Drone, it is possible to reaffirm the observations of flight stability and data collection by Neves et al (2015), since the RPA/Drone establishes practically inert height and positioning, making measurements with accuracy, highlighting its good characteristics for micrometeorological evaluations. Thereby, the use of RPA/Drone for sub-altitude radiosonde studies is suggested, either by improving the accuracy of data or by reducing operating costs.

\section{Acknowledgements}

Authors wish to thank the Center for Water Resources and Environmental Studies (CRHEA/USP), the Post-Graduate Program in Environmental Engineering Sciences of the University of São Paulo/São Carlos School of Engineering, Laboratory of Applied and Computational Physics (LAFAC) of USP/Pirassununga and the Air Force Academy (AFA) for the favorable structural conditions to carry out the research. To Brazilian Research Council (CNPq) for financial assistance.

\section{REFERENCES}


AMORIM, M.C.C.T. Ilhas de calor urbanas: métodos e técnicas de análise. Revista Brasileira de Climatologia., Edição Especial, p. 22-46, 2019.

ANDRÉ, J. C; MAHRT, L. The nocturnal surface inversion and influence of clearair radiative cooling. Atmospheric Measurement Techniques., v.8, n. 5, p. 864878, 1982.

BARBOSA, R.V.R. Estudo do campo térmico urbano de São Carlos (SP): análise da intensidade da ilha de calor urbano em episódio climático de verão. Tese (Doutorado em Ciências da Engenharia Ambiental) - Escola de Engenharia de São Carlos, Universidade de São Paulo, 2009.

BORNSTEIN, R. D. Observations of the Urban Heat Island Effect in New York City. Applied Meteorology and Climatology., v. 7, n. 4, p. 575-582, 1968.

CLARKE, J. F. Nocturnal urban boundary layer over Cincinnati, Ohio. Monthly Weather Review., v. 97, n. 8, p. 582-589, 1969.

CPTEC/INPE. Available in <www.cptec.inpe.br>. Access in: 5 mar. 2018

DAVIDSON, B. A. Summary of the New York urban air pollution dynamics Research program. Journal of the Air Pollution Control Association., v. 17, n.3, p. $154-158,1967$.

DEMARRAIS, G. A. Vertical temperature differences observed over an urban area. Bulletin of the American Meteorological Society., v. 8, p. 548-554, 1961.

DUCKWORTH, F. S.; SANDBERG, J. S. The effect of cities upon horizontal and vertical temperature gradients. Bulletin of the American Meteorological Society., v. 35, p. 198-207, 1954.

EARTH PRO. Available in < www.google.com/earth>. Access in: 15 mar. 2018.

EMBRAPA. Available in < http://www.cppse.embrapa.br/meteorologia>. Access in: 11 nov. 2018.

GEORGII, H. W.; JOST, D.; SHAEFFER, H. J. Über die rumliche und zeitliche Verteilung von Schwefeldioxid und Sulfataerosolen in der unteren Troposhare. Scientific Report, Institute of Meteorology and Geophysics, University of Frankfurt/Main, 1968. 55 p.

GODOWITCH, J. M. et al. Evolution of the nocturnal inversion layer at an urban and nonurban location. Journal of Climate And Applied Meteorology, v.24, p. 791-804, 1985.

HART, M.A; SAILOR, D.J. Quantifying the influence of land-use and surface characteristics on spatial variability in the urban heat island. Theoretical and Applied Climatology, v.95, n. 3-4, p. 397-406, 2008.

IBGE. Available in < www.ibge.gov.br>. Access in: 22 dec. 2018.

IPMET/UNESP. Available in < www.ipmet.unesp.br>. Access in: 5 mar. 2018.

MAHRT, L. Stratified atmospheric boundary layers. Boundary-Layer Meteorology, v. 90, n. 3, p.375-396, 1999.

MESTAYER, P.G et al. The urban boundary-layer field campaign in Marseille (UBL/CLU-ESCOMPTE): set-up and first results. Boundary-Layer Meteorology, v. 114 , p. 315-365, 2005. 
NEVES, G.Z.F. et al. Avaliação termo-higrométrica de sub-altitude utilizando balão cativo e quadrotor: um ensaio experimental. In: Simpósio do curso de pós-graduação em Ciências da Engenharia Ambiental, 14., São Carlos. Anais. São Carlos: PPG-SEA, 2015. p. 96-106.

OKE, T. R. Boundary Layer Climates. London: Methuem \& Ltd. A. Halsted Press Book, John Wiley \& Sons, New York, 1978, 372p.

$\mathrm{PAL}$, S. et al. Spatio-temporal variability of the atmospheric boundary layer depth over the Paris agglomeration: an assessment of the impact of the urban heat island intensity. Atmospheric Environment., v. 63, p. 261-275, 2012.. 